GENERAL SBO ELECTRIC conan

$\circ$

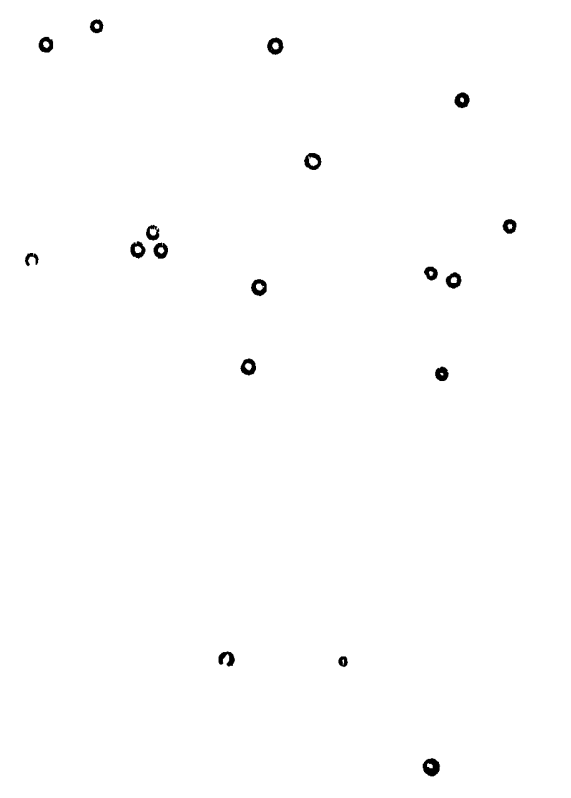

$\hat{\text { }}$

- A. B. Greninger Mnager, Englneerling 703 BLDG., 700 AREA •
DE93 003404

i. WE Johnson

2 - 7. AB Oreninger

8. OJE Malder

9. HM Parker

10. DM Johnson

11. RH Beaton

12. Js McMahon

13. WK Woods

14. RB Richards

- 15. WK MacCready

16. CA Prlode

17. RS Bell

18. WM Mith1s

19. PH ReInker

20. VR Cooper

21. LP Bupp

22. JJ Cadveli

23. WJ Ozerors

24. OH Oreaber

25. 300 F110

26. Yellow
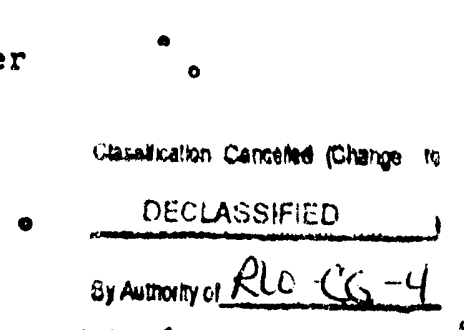

CA Bauman 12-4-91

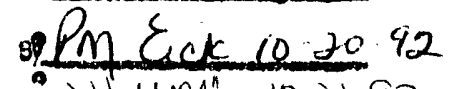

- J) unibo 10.21 .92

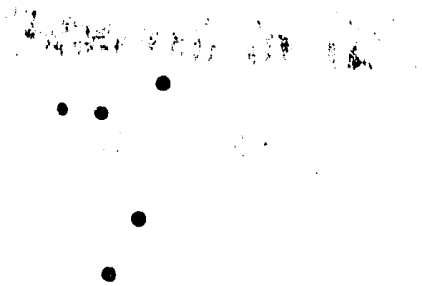

My 31, 1955

\title{
FUTURE POWLR LEVELS OF HANFORD PILES
}

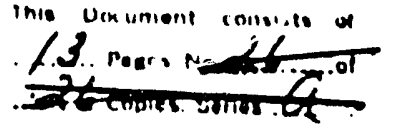

copy I ut

Th1s document has been prepared in response to a recent request from the Atomle Energy Coundusion for a brief review of the princlpal 1deas and technical developments which might affect power levelo over the next olx years. Also requested vere approximate date on any plle modislcat1ons that might be involved, Including rough estimates covering possible coot and complet1or. dates.

The forecasts vich follow must be presented wh th a number of Important quall. oflcations. It has been ansumed, r1rst of all, that much better alugs will be developed lliring this perlod, and at ate which will keep pace with the increasingly severe wervice requirements of higher and higher p1le pover levels.

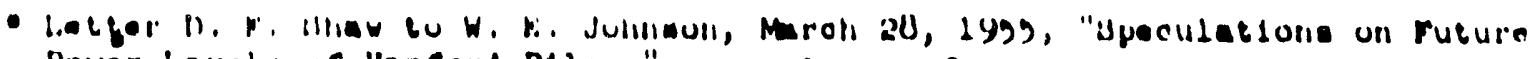

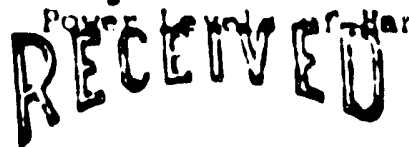

sur $\theta$ iso

3i? DREA -ra i.nry. 


\section{DECLASSIFIED}

A. B. Greninger

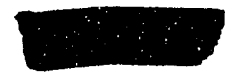

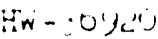

A.

$-2$

May 31, 1955

-

0

0

○

The ent1re forecast 18 iependent upon timely reglization of this prime ooject1ve of Plle Tectinology program. The timing projected for achlevement of varlous increments in plle power has been estimated on the basis of favorable results in a continuing research and revelopment profram; it likewhe has been assumed that budgetary provlsion for necessary capltal outlays

wll be stralghtforward matter based upon an undlminlshgd demand foro further
produlion. produetion.

An opt1mistic approach of this kind eppears to be well taken fn any opeculation as to the possible course of pile pgwer levels over the noxt few years. While such speculatife forecasts cannot be considered as commitments in any sense, it is our plan to revise the flgures each year and thus through repeated refining and adjustment of the predicted level to arrive eventually at figures whlch should provlde a ound approach to the overall planning problem.

SUMPARY: 0000 0000

A brief discustion of plans Ior increasing the pover levels of the Hanford Plies 1s provlded. This document does not attempt to outline an overall plan for the Hanford Atomlc Products Operation and no consideration 18 given here to the basic question of when 1t may become desirable to bulld now plles rather than to 1mprove existing units. It w1ll also require surther study and development work to resolve the ultimate question of whether 1t feaniblo and economlcally desirable to convert the plles to recirculation.

Within these limltations, the plans for 1ncreasing power levels involve the iollowlng imurovements to the p1les: 0

1. Project CQ-558 for 1ncreasing the totel vater flov ratee of the $B, D$, and DR P1les to $71,000-74,000 \mathrm{spm}$ and $91 \mathrm{milar}$ project fo: the $F$ and R.piles.

0

2. Profece co -600 for Ingreasing the total water flow rate at the C P1le to $94,000 \mathrm{Bpm}$.

3. Development of methods of reducing olug corrosion and to a lessero extent, tube corrosion.

4. Increase of the total llow rate through the $K \beta_{1108}$ to the maximum - capacity of the process pumps - about 165,000 spm.

5. Solving problemsossociated wth presourization of the rear face plping to allov maximum tubceoutl-c temperatures of about $160 \mathrm{C}$ at the $B, D, D R, F$, and $F$ P1les, and of about $145 \mathrm{C}$ at the $C, K E$, and KW P1les.

0

$\odot \bullet$

\section{DISCLAIMER}

This riport was prepared as an account of work sponsored by an agency of the United States Government. Neither the United States Government nor any agency thereof, nor any of their - employees, makes any warranty, express or implied, or assumes any legal liability or responsibility for the accuracy, completeness, or usefulness of any information, apparatus, product, or process disclosed, or represents that its use would not infringe privately owned rights. Reference herein to any specific commercial product, process, or service by trade name, trademark, manufacturer, or otherwise does not necessarily constitute or imply its endorsement, recommendation, or favoring by the United States Government or any agency thereof. The views and opinions of authors expressed herein do not necessarily state or reflect those of the United States Government or any agency thereof. 


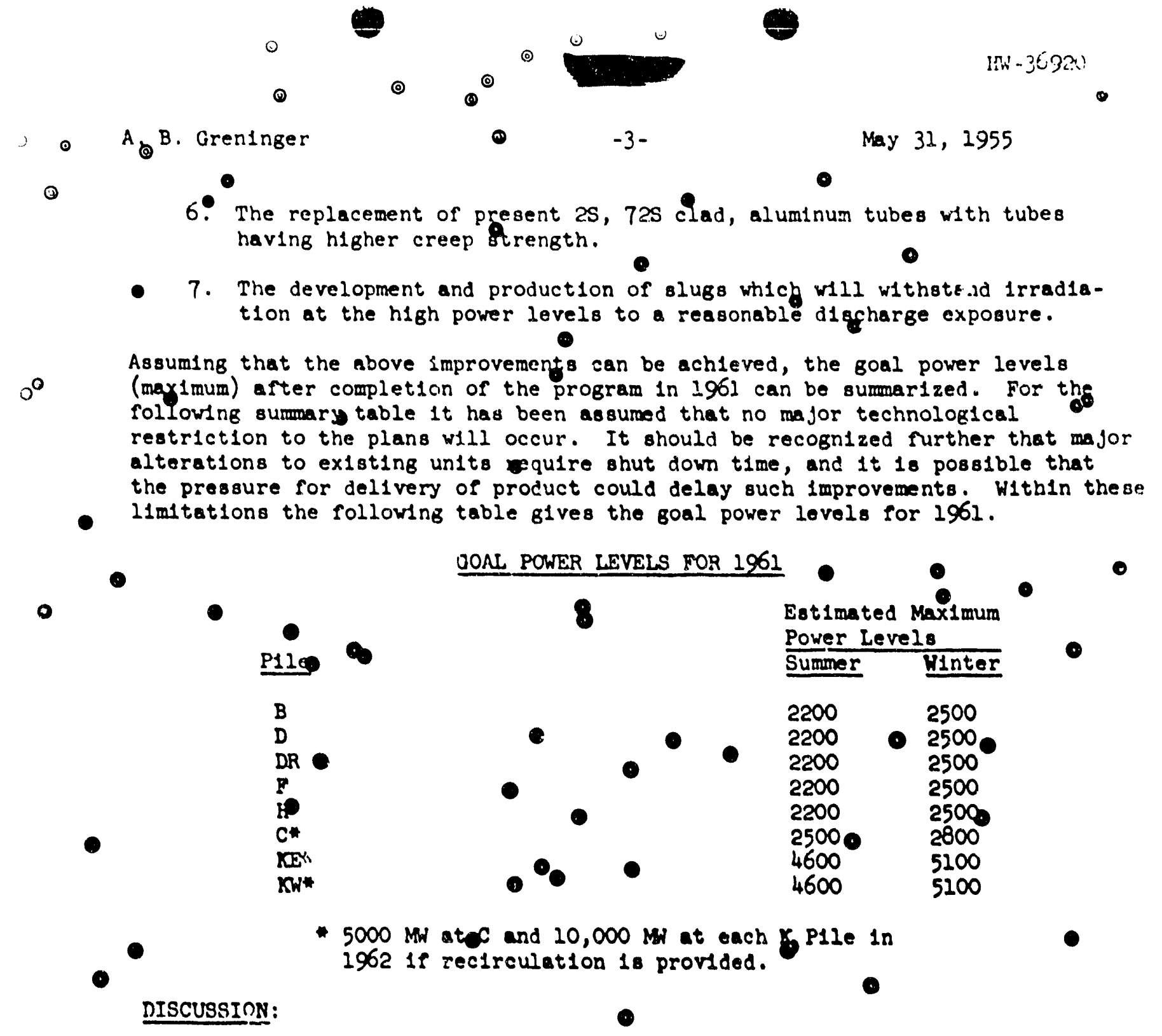

1. Proces 8 changes and approped or der1nitely planned elant modiflcations which produce increases in production.

3

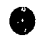

A. Project CO-558

- Thio project 1s divided into two phases. Briefly, Phase I of this pepject consists of the following:

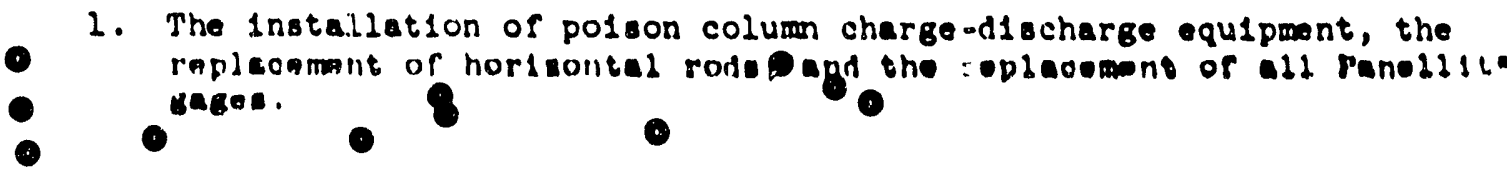

- A Parlelilt gage Indicates the presaure at the venturl throat or or1f1ce just upstream of the inlet of each process Qtube.

-

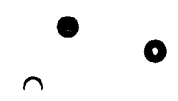




\section{DECLASSIFIED}

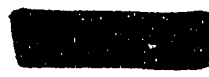

(1)

May 31, 1955

A. B. Greninger

(1)

$-4-$

2. Modifications of the water plants and inlet piping and fittings

of the $B, D$, and $D R$ P1les to produce total flow rates of 71,000 to 74,000 gpm as compared to present flow rates of 48,000 to 53,000 spm.

3. The preparation of detalled design for the modiflcations of "2", above, for the $F$ and $H$ Plles.

It 18 expected that theoncreased water flow rate w1ll become avallable at the following times.

D Plle - March 1, 1957

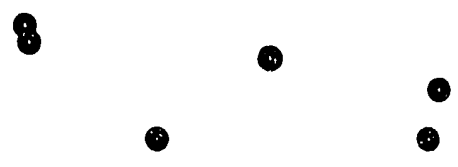

Within a very few months thereafter power increase percentages equivalent OP to the percentage of Ilow rate Increase ( 40 to 45 per cent) should result, provided that slugs sufflciently rupture resistant are avallable, and that for the slugs which are avallable, the exposure can be low enough to prevent

- an excegsive rupture rate.

The est1mated total project cost for Phase I 18 $\$ 26,9 \$ 4,000$ Including $\$ 184,000$ transferred capital property, and not including shutdown time. A total of about ten plle months of shutdoin time 18 required. Nearly 1600 megavatts of additional production capacity should result.

B. Project CG -600 for the C P11e

The flow rate at the $c$ P1le w11 be Increased from 83,000 to about $86,000 \mathrm{gpm}$ by the Installation of new front nozzles, I1ttings and connectors elther early or late in 1946. During the Sumwer or Fall of 1946, the preaent process pirms will be replaced with new, mo:e efflclent pumps, raising the total rlow rate to $94,000 \mathrm{gpm}$.

-

The est1mated total project cost, exclusive of the cost of about three weeks shutdown t1me, $18 \$ 1,000,000$. About 260 megawatts of add1t1onal product1on - capac1ty w111 result.

C. Process changes other than major plant modiflcat1ons

These process change consist of the expected ochedule for raloling the limitations to p1le process tube and bulk outlet water temperatures, p1le graphlte temperatures, and of the use of enrichment for increasing power levelo, 1: tube outlot tomperature 11mito are not high enough to make onrlehment unsecessary. Briefly, technology mast be developed oo that changes in procese $11 \mathrm{melta}$ can be made e rollow:

1. Incroses of the bulk outlet temperature 11 m1t to $100 \mathrm{C}$ as the result of p1le testing.

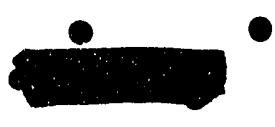


○

A. B. Greninger

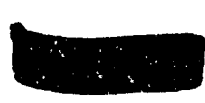

$\odot$
$\operatorname{Hin}-36920$

May 31, 1955

2. Increase slug and tube corrosion limlts by successive steps of process water $\mathrm{pH}$ reduction from the present 7.3 to 7.0 , and some

- value below 7.0. It 18 hoped that the tube outlet vater temperature liglts for $800 \mathrm{MWD} / \mathrm{T}$ slug exposure can be increased in steps to $135 \mathrm{C}$ by the se $\mathrm{pH}$ changes. Preliminary testing has shom that cons1derable increases are probable, and further testing is in progress to determine magnitudes.

3. Effective ellmination of graphite temperafure 11 mit for the highest power levels as the result of small scale and full pile tests, now in progress.

4. Increase of tubeloutlet water temperature 11 mt ts necessary to prevent unstuble boiling in the process tubes to 130 - $135 \mathrm{C}$ by minor pressurization of the rear crossheaders, and by development of more Information on tube bolling and 1ts effects. To achleve limits higher than $130-135 \mathrm{C}$, modiflcation of rear plf dis will be required, and 111 have to be done under auspices of a project. This project will be discussed in a later section.

The foregoing changes in process limlts are expected to have the effect of Increasing power levels up to that allowed by the $100 \mathrm{C}$ bulk outlet temperature 11mit by the Sunmer of 1946. In August and September 19j6, when the - Inlet vater temperature is $20 \mathrm{C}$, resulting power levels for the total flow rates which would exist $8 t$ that time are shown below. Maximum Winter pover levels ( $5 \mathrm{C}$ inlet) for this limlt are also shown.

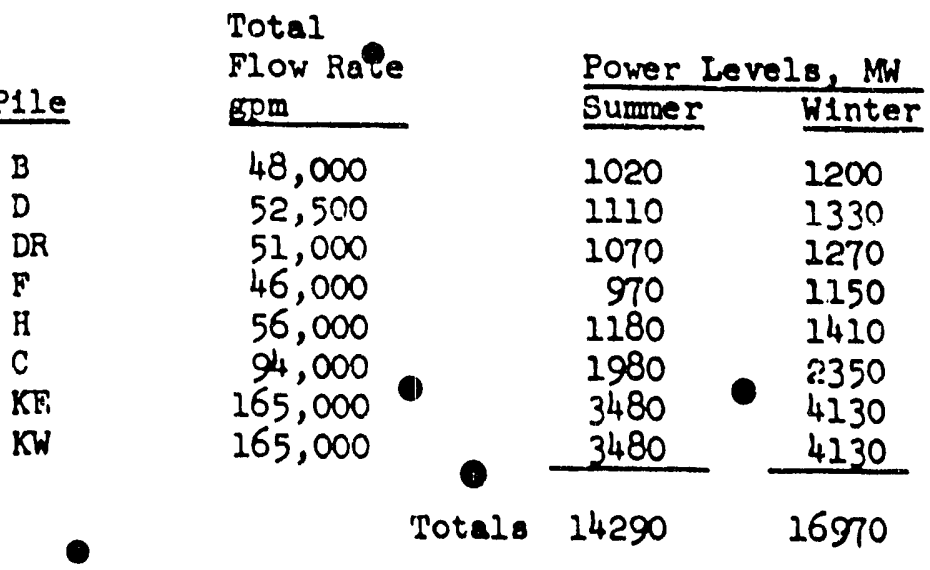

D. Other process 1mprovements necessary to achleve these pover levels or to increase production by 1ncreasing the time operated efflelency are as follows:

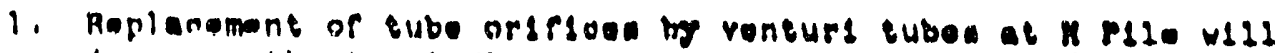
Inorease the totel flow rate from $52,000 \mathrm{spm}$ to $56,000 \mathrm{cpm}$.

2. Resett1ng the presaure 1ndiceting ranges of the $K$ P1le Panell1t gages wil allow the total flow rate to be increased from 138,000 8pm to 165, 00n erm.

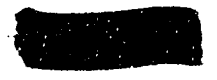


A. B. Bianinerer

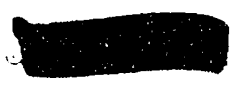

$-6-$
- My 31, 1955
3

3. The development of slugs which wll not have excessive rupture rates at the expected speciflc powers w1ll be necessary. Present slugs would probably be sultable for the above fower levels at the $B, D, D R, F$ and ï Plies thougin some reduction in exposure may be Recessary. At the $C$ and $X$ Plles, partlcularly the $C$ Pfle, the sultablilty of present slugs is not likely, even for production of low exposure product $(200-300 \mathrm{MND} / \mathrm{T})$. New slug types wolld probably be required. A serles of new olug lypes have recently been tested. In thelr present state of development, none of these slugs has show superforlty over present solld sluss. However, internallyexternally cooled cored slugs have not yet been adequately tested. One modiflcation of the externzl'y cooled cored slug has been developed since Initial testing and will be tested shortly.

Metallurgical examination of the experimental slug fallures is in progress. From this work and from new developments, it 18 expected that a superior slug will be developed.

4. Completion of the replacement of the hor1zontal control rods and their thimbles with new rods sealed at the plle face w11l be requirer. Th18 work 18 a part of Project $C G-558$ and w11 probably be completed shortly. Off the rods were not replaced, porer level would have to be restricted to prevent softening and sagging of the thimbles.

5. New, 1mproved p1le temperature Instrimentation 18 needed to assure plle safety. Operatifis power levels up to that allowed by a $100 \mathrm{C}$ bulk temperature rise could be made without addition to or modification of the Instrimentation other than increase of the indicating range of temperature and power level measuring inotrumenta. Hovever, both plle cafety and time-opereted efflclency would be Improved by the 1nstallation of terperature devicen on 100 to 150 selected process tubes. These devices would automat 1 gally ind1cate approach to unsafe temperatures, allowing better temperature control, particularly on startupe after brief shutdoms. The devices vould also shut the plie dom automatically before unsafe temperatures vere sttalned. The project proposal for th1s work 18 oelag prepared. It to expected that the total project cost w1l be about $\$ 500,000$ for the $B, C, D$, $D R, F$ and $B$ P1les, and that the couplet1on date v1ld be Sumer or early pall of 1946. At the $K$ plles, the only work required to estab-

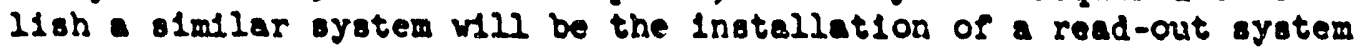
for outlet temperatures of selected tubes vith varning for approach to uneare temperatures. Th1s rork can probably be done at a cost of about $\$ 30,000$.

6. Replacement 28 planned of the presen oyaten which monttora princ1pally the beta activity of the procek water at each end of each rear croosheader for tre purpose of detereing elue ruptures. The replacowant gyotem 18 acint1liation-tipe gamm rey monitor wich will monltor vater from the sam sources. Carlier and more defindte detection of alus ruptures hould be posalble. Th1s should effect
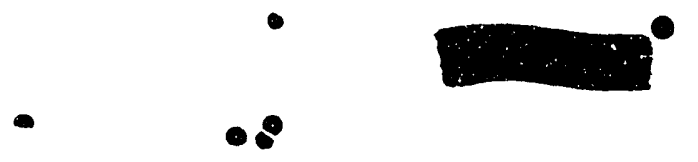


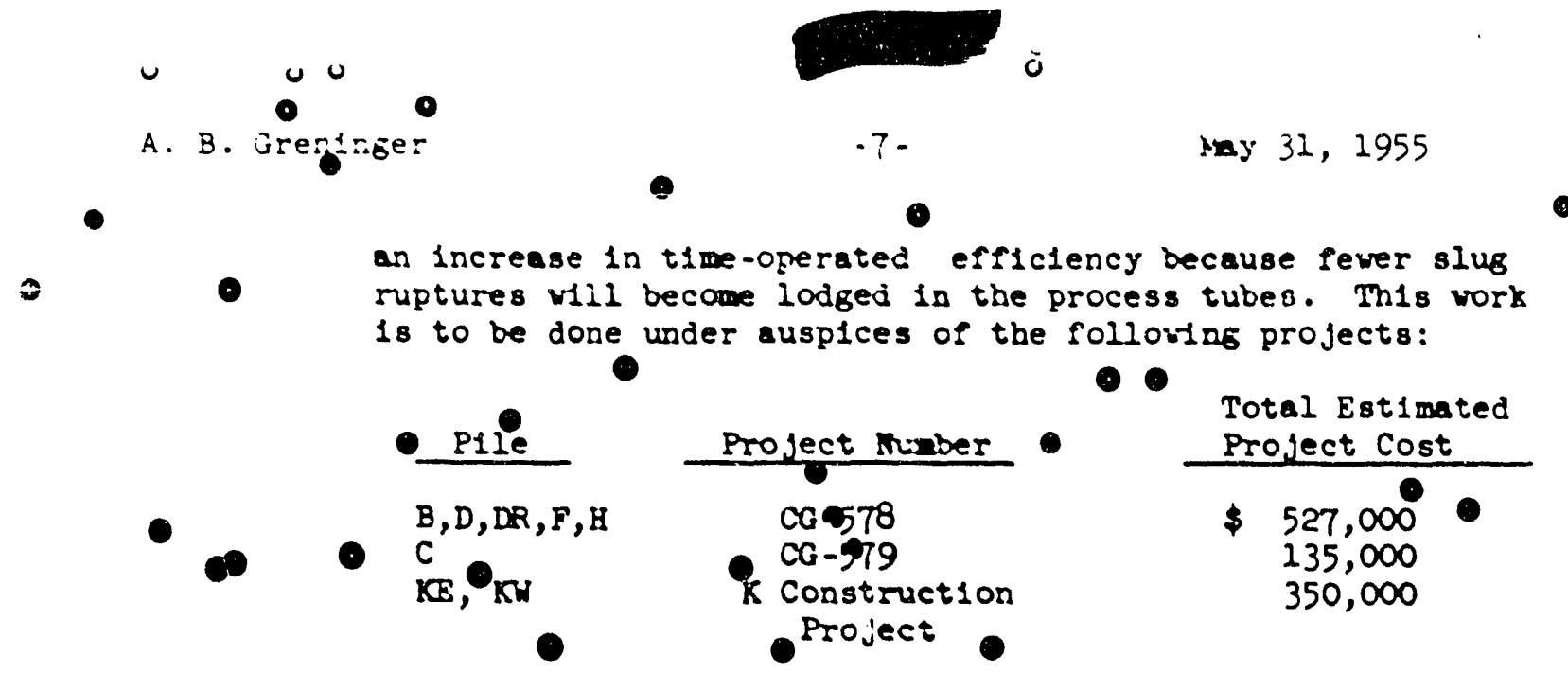

For operation at and above $100 \mathrm{C}$ bulk outivet temperatues some difflculty caused by the temperature of the vater sample lay be experfenced. Development vork is presently in progress to define and solve this problem. It 18 expected that mod1f1cat1ons necessary for the ellmination of this problem cas be made under auspices of the respectire projects.

7. The use of sufficlent enrlchment to mintald 1380 effect1re pover tubes* at the B, D, DR, F and B P1les, 1460 effect1ve power tubes at the C P1le, and 2300 effectire porer tubes at the $K$ Ples would be required to prevent restriction by tube outlet temperature IImits to lover pover level than lloved by the $100 \mathrm{C}$ bulx outlet temperature 11mit. Th1s assumes that the lovest tube outlet temperature liedt wlll be $130 \mathrm{C}$, as catated in part $\mathrm{C}-4$. If tube outlet temperature limfte are lower, the malntenarce of a higher number of offectire tubes could probably be econombelly just1gled.

8. Installation of 1uprored, faster acting rertical safety rods 18 plarned. Th1s 18 not necessary for the attalnment of the quoted power levels, but can be fustifled on tha basis of lmproved p1le safety. New rods would be regulred for the B, C, D, DR, F and $B$ Plies, allght modiflcation of the $X$ Plle rods 18 necessarj. Total budgeted cost 1. \$4,650,000.

99. Also justifled on the basis of p1le safety an be tib Installation of tube-outllet-terperature-seneltive atomatle shutdowa derlces on erery tube, and tise proplsion of bev or aodifled tube flow measuring derices. A totel of $\$ 7,250,000$ bas been budgeted of these 1tems and also for possible 1astallation of derices measuring locel power level rising per1ods.

R. Fover Lerels Broduced

The completion of all the 1tem lieted in parts $A, B$, and $C$ are expicted to

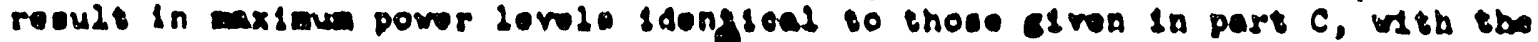
?

- No. of Brfective Power Tubes (Pover Lerel)/(Malmu rube Pover) -

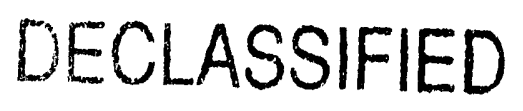




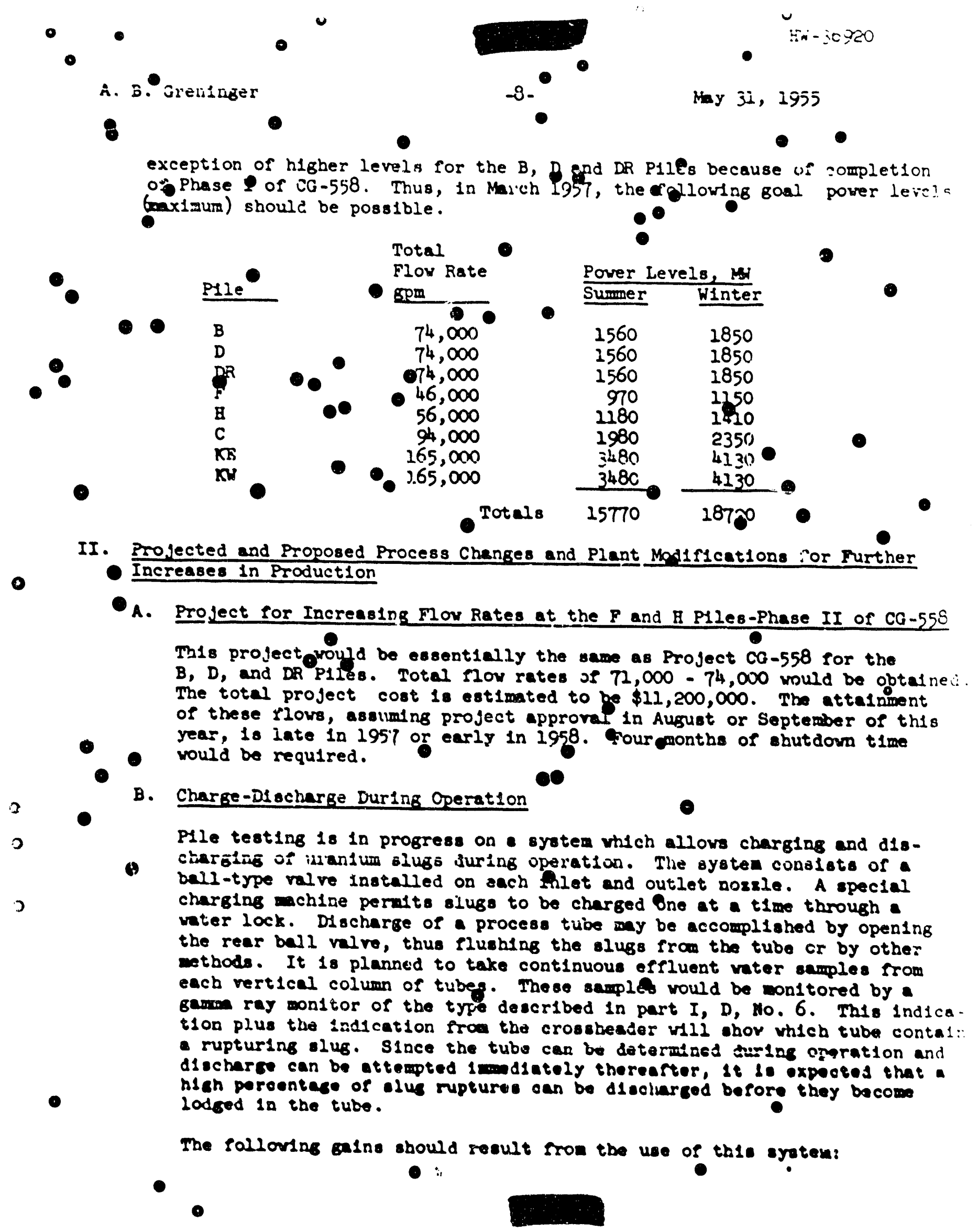


00

A. B. Greninge: $0^{\circ}$

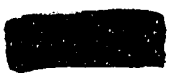

-
$-9-$ $\bullet$ $\because-\cdots$

May 3201955

1. Five eo ter per cent production would be galsed, deperding on the uranfum throughput rate, because of the elizination of shut iow time

$\bullet$ and lov-power-level operating time.

2. Shutcorn time now required for removal of slug ruptures stould be Peduced. Consequently, if porer is limited by rufture rite economles,

○

-

0

$\bullet$ highe povers could be achiered.

3. Improvement of operating power distribution

- 0 two to four per cent.

-

First 1nstallation of this system is planned by September 1956 for the C Plle

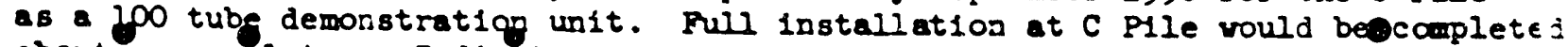
about a year later. Indicated cost for the C P1le is about $\$ 1,800,000$. Application to the K P1le is belng studied. A possible completion date at the $\mathrm{K}$ Plles 1s Spring 1959, and est1maten sost for the 1nstallation at both piles is of the ordereof $\$ 5,500,000$.

\section{Pressur1zotion}

$\odot$

Pressurization of he rear piping to.llow higher bulk outlet temeratures is under stujy. In general, pressurization would be effected by placing a restriction restrictions in the efeluent piping at one of the pollowing locations:

1. At the rear of each tube.

- 2. At both ends of each crossheader.

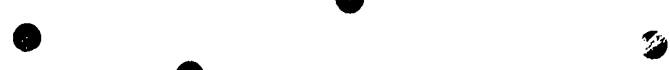

3. At the top of each rlser or between the r1sers ani the dommcomer.

4. In the downcomer.

- 5 - Between the downcomer and the retention basins.

To dispose of the large rolume of sti:an which vill be generated, one of the folfowling three methods wll be used. 1. Addition of relatively low cost, low pressuy "queach" vater upstrean of
the flow restiflion.

2. Electrical power recovery.

3. D1scharge of stewn from a stean separator into the atmophere.

of these alternatives, the use of queach witer has been gore thoroughly 1nrest1-

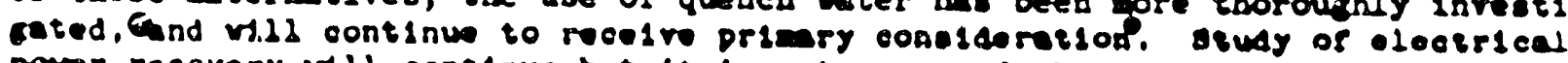
pover recovery vill contlaue but it 1s not expected that anj electrical pover re. covery systes vould be put Into operation before 1961 or 1962 . D1scharge to the atsosphere has undesirable radiological and ateorologlcal efrects, but ban not been deflattely elirinated from consideration. 
4

0

○

A. B. Greninger

\section{DECLASSIFIED}

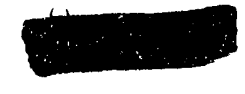

$\mathrm{KN}-.30920$
May 31, 1955 .

Preliminary co\& gstimass of pressurlzation with quench water and with the restriction at locations $2,3,4$ and 5 above, have been made. The least expersive appears to be alternative 2 , 1.e. restriction at both ends ol each crossheader.o With this alternative, two new rlsers would be installed on the rear face to supply water upstream of each restrlction. River water would be supplied to these risers through a gew plpe line from new pumps. The river pump house would be enlarged to accomodate these pumps, and provlston would be made for Increased pressure in the junction boxes of the effluent line, provision to pump water from certaln process drains into the effluent system would be requiredo Total estimated cost of this system is of the order of $\$ 3,000,000$ per reactor. It

0 should be emphasized that th1s 18 one alternative that now appears possible. Continued 1nvestigistion may show that moreoextensive modification 18 required, or that other alternatives are more desirable.

כ

W1th this system 1nstalled, The rear face pressure could be ralged to the max1mum value economically desirablo for the existing vatero plast. This thaximur is dependent on the vay that tube flow races and tube bo1j.1ng outlet temperature limits vary with the pressurization pressure used. Increasing th1s pressure increases the tube bolling limtt. However, as this pressure is increased, the inlet pressure can be increased to malntein tube flow rates only to a flxed polnt. As the rear face $\mathrm{g}$ sssure 18 further increased, polnt 18 s00n reached at which - furtber 1ncrease vould cause a decrease in allovable power. For tubes having annulus sizes the same as presefity used, calculations have shown the following maximum tube outlet temperatures:

-

\section{-}

•

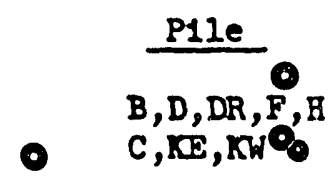

•

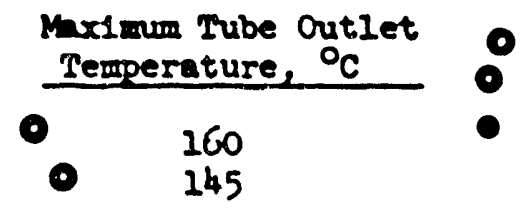

However, tests may show that these temperatures are elther h1gh or low. In particular, the value for $C, K E$ and $K W$ has been only roughly calculated. Detalled study and testing vill be requared.

At the B, D, DR, F and B P1les; wore flow and thus more power cen be achleved by 10creasing the annulus s1ze. The opt1mum annulus size bas not been determined

- but 18 somewhere betgeen the sizes presently used at B and C P1zes. Tresumably, th1s would be done by decreasing sikg dlameter, although it is possible that a tube waterlal having sufficlent strength ind corrosion resistance to allow thinner wall construction will be found sultable. To achieve these tube outlet temperatures several other 1mfrovements wll be necessary in addition to solution of all the design problems assoclated with pregurization and high outlet temperaco tures. These are:

2. The maximum tube outlet teuperatures of present tubes ar. the proposed

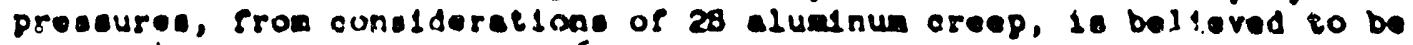
about $140 \mathrm{C}$. Tubes made of 635 alund num, which has about twice tho creep strengtb of $2 S$ are belng tested. It 1 expected that tubes of 635 or some other alloy would be lastalled at the same tios as pressurization equipment at the B, D, DR, P and $B$ P1les. Th1s cost 18 not included 
A. B. Greninger

00

o

0

\section{๑}

o

0 $-11-0$

Way 31, 1955

(1) o

Instalnat in the current estimate of $\$ 3,000,000$. Installation of new tubes at ${ }^{\circ}$ the $C$ and $K$ Plles may not be necessary but if needed, would probably be done only as oldotubes required replacement. Zirconlum tubes are also

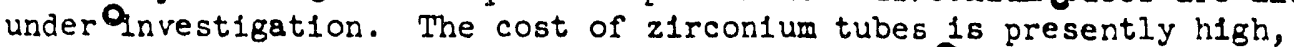
but wall undoubtedly decrease 1n the future. The Gustification for the use of zirconium tubes depends on the process tube outlet water tempera- 0 tures achievable with tubes of 21 rcontum as compared to aluminum, and on the relative costs, Including later replacement requirements, of tuber of the two mater1af8. Because the above foformation cannot now be predic Ped $^{\circ}$ with reasonable accuracy, the lowest outlet temperature at which use of ozirconium is desirable is not known. However, rough est1mations range from 140 to $170^{\circ} \mathrm{C}$. Continued derelopmentoand testing of zirconlum tubes O is necessary because there is a falr Qhance that they 111 prove desirable and also because of the possibilities for recirculation of the cooling water with sill higher water temperatures.

$$
0
$$

2. Increase of slug and tube corrosion 11 mits to $160 \mathrm{C}$ tube outlet temperature 0 will be necessaryo The planned schedule of $\mathrm{pH}$ reduction $1 \mathrm{~s}$ expected to allow tube corrosion limits of $260 \mathrm{C}$ and slus corrosion limits for $600 \mathrm{MTD} / \mathrm{T}$ exposures of $140 \mathrm{C}$ by the mlddle or last of 1957 . By the end of 1958, further Impiovement by increasing can wall thlckness or some other change may allow $160 \mathrm{C}$ for slugs exposed to $600 \mathrm{MWD} / \mathrm{T}$.

03. The bargest uncertainty in achieving these maximum temperatures is slug quality. B9 slug quality is meant the resistance of the slugs to ruptures

(.) caused by uranlum cleavage or fallure. OAn intensive derelopment program to produce slugs which will withstand high speciflc govers at reasonable exposures 18 underway.

$\bullet^{\bullet}$

0 Wh1le there 1o some possfbll1ty that sol1d cores w1ll operate sat1sfactorily wth the centers in the $\beta$ phase $(\sim 660 \mathrm{c})$ it appears unlikely that they would operate in the $r$ phase - a condsflon which would be imposed by the 110 - $120 \mathrm{~kW} / \mathrm{ft}$. spec1f1c power and $160 \mathrm{C}$ outlet temperatures contemplated after pressurization of the rear piping. One solution might be alus with increased surface to volume rat10. The least radical alteration of present geometry 18 the internally-externally cooled slug already ment1oned. The

- proposed specifle powers vilP 1mpose severe stressesoon even this slug. Other solutions may be possible.

0

Pose1bleocompletion dates for pressurization are of course quite tentative. It 1s hoped that modiflcations could be completed by some time in 1961 . Goal Sumer and

○ Hinter power level8 (maximum) are glven below:

○

○

o

o
○

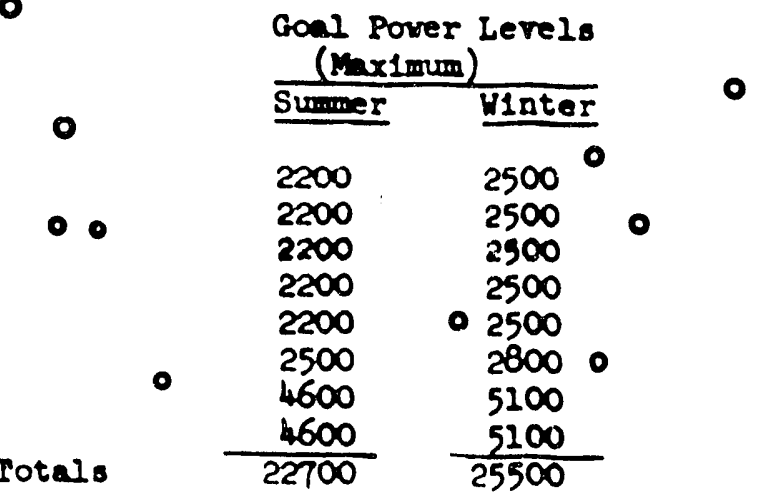

Goal Power Level. $\frac{\text { (Maximum) }}{\text { Sumer }} 0$

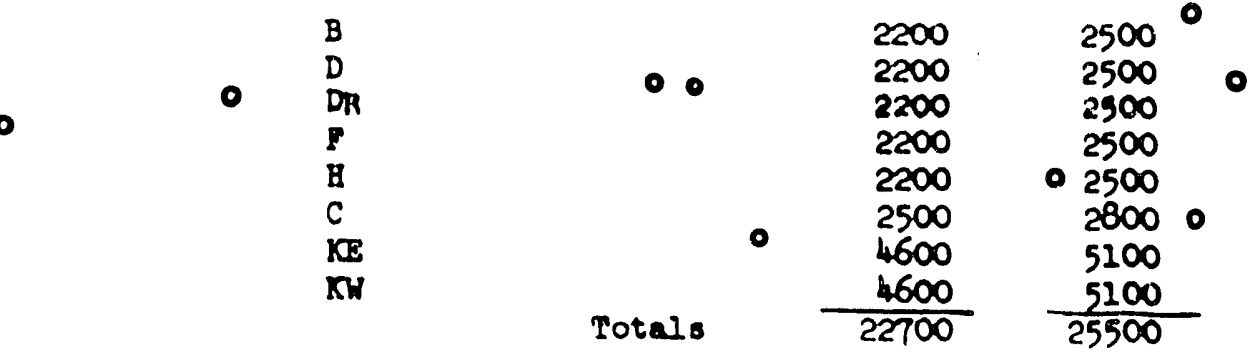




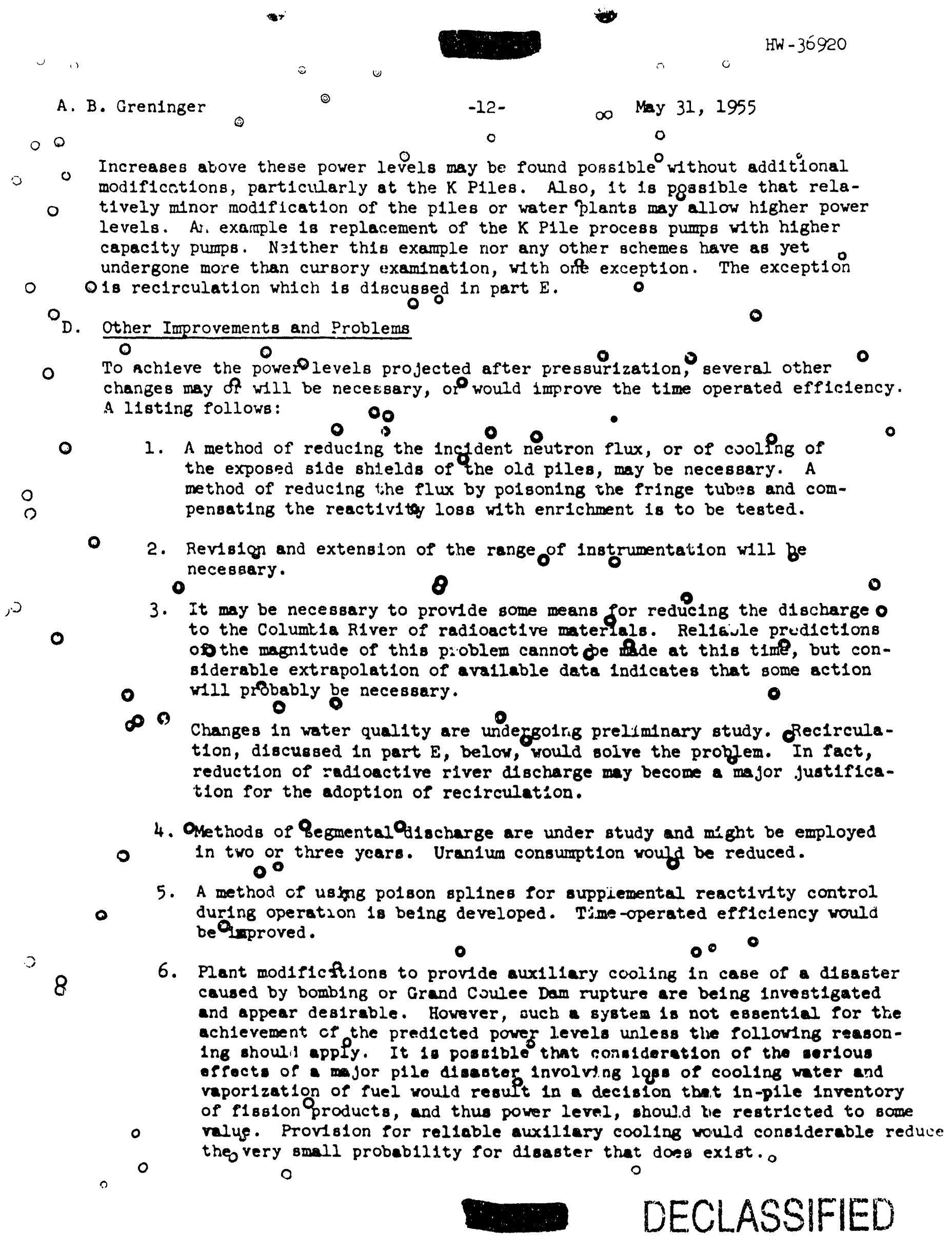




\section{DECLASSIFIED}

A. B. Greninger

$$
0 \quad 00
$$

May 31, 1955

3. New nozzles ard new methods of process tube closure are beli:s 0 developed. These would allow replacement of process tubes without nozzle removal, and $80^{\circ}$ would save shutdown time. 0

E. Recirculation

$\circ$

80

A study of recirculation was reported in document HW-30907-RD. "Economic Evaluation or Recirculation \&s a Method of P1le Coollng", (4-7-54). The general conclusion of this repor', was that reclrculation at high outlet temperatures is economically attractive, if a number of assumptions were found true, and that reclrculation whth high outlet temperatures oshouid be tested and further 1nvestigated. :

0

$\circ$

Investigation 18 in progress and in-pile testing will soon begin? It is expected that by 1958, sufficlent technology will have been demonstrated oto provide design bases for plle alterations. Project study on these bases 0 through 1959 could lead to firm plans for conversion to recirculation, provided economic desirability exists at that t1me. o Construction might then be possible in 1961. Provisions for pressurization previously completed would probably be largely sdaptable to recirculation. The mostollkely piles for application of recirculation are the $K$ and $C$ P1les. Pover levels would be in the range of 5,000 and 100,000 megawatts at the $C$ and at each $K$ P1le, respectively. Reference to Case 5, pages 57 and 58 of document EW..30907, may be made for deta1ls $8 \mathrm{n}$ the most probable installation.

0

0

OB Greager:khs

○

$\circ \quad 0$

$\circ$<smiles>Oc1ccc(O)c(O)c1</smiles>

$\circ$

0

$\circ$

$\circ$
○

0

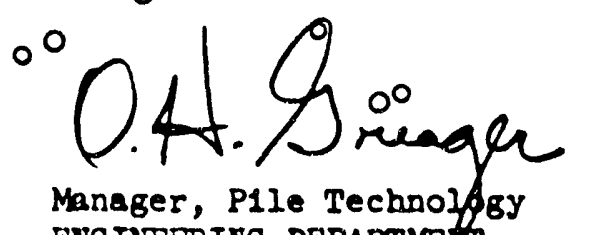
ENGINEERING DEPARTMEII 00

$\circ$<smiles>C1CCCCC1</smiles>

0

$\circ$

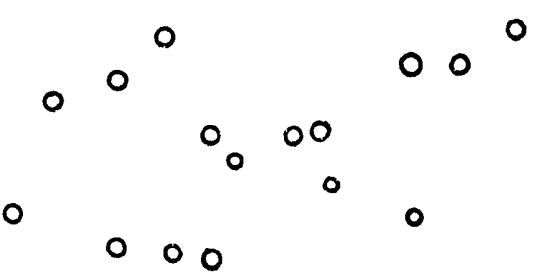<smiles></smiles>

DECLASSIFIED 

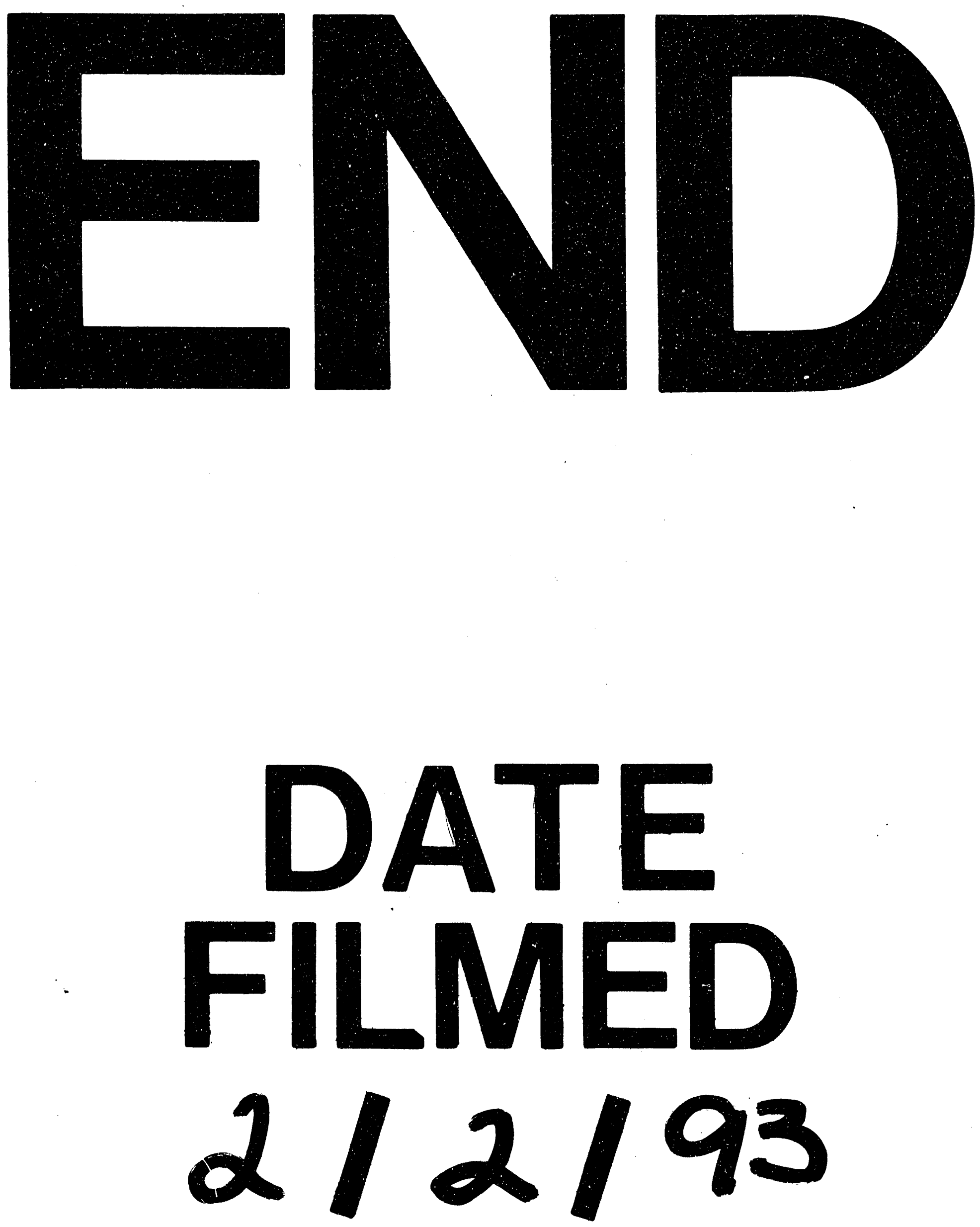
